\title{
ISOLATION OF ANTIBIOTIC PRODUCING BACTERIA FROM SOIL
}

\author{
Ruby Khan ${ }^{1, *}$ \\ ${ }^{1}$ Silesian University of Technology, Gliwice, \\ Akademicka 2A, 44-100 Gliwice, Poland
}

Current Trends in

Natural Sciences

\begin{abstract}
Antibiotics are a major secondary metabolite produced by a wide range of bacteria. The microbes developed various antibiotics that could be used to treat various infectious diseases. Are useful In vitro isolation, the culture and care of bacteria are quite simple, and we can easily improve their stress. The main soil pathogens of the Bacillus species are caused by important antibiotics such as bactericidal Endospores produced by the Bacillus species are very resistant. They are always found to inhibit the growth of other microbes. In the present research study, soil bacteria with antimicrobial activity have been screened and isolated. Subsequently, various pathogenic bacterial lawns were prepared to check the antimicrobial activity against various pathogens. Different zones are observed against different pathogenic bacteria. Comparison of antimicrobial activity of soil isolation with different antibiotic discs as well as various pathogenic bacteria. A clear zone of soil isolates of $5 \mathrm{~mm}, 15 \mathrm{~mm}, 21 \mathrm{~mm}, 12 \mathrm{~mm}, 30 \mathrm{~mm}, 32 \mathrm{~mm}$ and $40 \mathrm{~mm}$ against germs or pathogenic bacteria. The zones produced by antibiotic discs against pathogenic bacteria were zones of $5 \mathrm{~mm}, 10 \mathrm{~mm}, 12 \mathrm{~mm}, 15 \mathrm{~mm}, 20 \mathrm{~mm}$, and $21 \mathrm{~mm}$ observed.
\end{abstract}

Keywords: Antibiotics, Pathogenic bacteria, Soil isolates, Zones of inhibition.

\section{INTRODUCTION}

The problem of antibiotic resistance in bacteria is increasing day by day. Therefore, there is an urgent need to find new antibiotics or new sources of antibiotics. There has been a lot of work over the last few decades, which has seen the development of novel antibiotics from different microorganisms (Mashoria et al., 2013). The term soil refers to the outer loose material of the earth's crust. Soil consists of five major components, among them. Minerals, H, water, organic matter, H, air and living organisms (Abdulkadir and Waliyu, 2012). The soil is a natural reservoir of microorganisms and their antimicrobial products (Dancer, 2004). The production of antibiotics is one of the most important mechanisms for controlling plant diseases with live microorganisms (Chang et al., 2010). Serious bacterial infections that have become resistant to commonly used antibiotics have become a major global health problem in the 21 st century (Ceylon et al., 2008). At the beginning of the 20th century, the idea of stopping the growth of microorganisms around each other came up. Later, it was revealed that the inhibition of the growth of the former microorganisms was mediated by the secretion of toxic metabolites. This toxic metabolite was described as 'antibiotic' (Singh and Mishra, 2013). Soil bacteria belonging to the genus Stoptomyces are widely recognized as industrially important microorganisms because of their ability to produce a variety of secondary metabolites, including antibiotics. Actinomycetes have provided important 
commercial bioactive compounds of high commercial value and have been regularly tested for new bioactive substances (Methor et al., 2012). Antimicrobial agents play the most important role in the treatment of bacterial infections. Antibiotics can be classified according to them behavior. Antibiotics are classified as broad-spectrum antibiotics when they have the potential to infect a wide range of Gram-positive and Gram-negative bacteria, while antibiotics that are effective only against a specific group of bacteria Spectrum is known as antibiotics. Since Fleming's discovery of Penicillin notatium in 1929, and the widespread treatment of this agent in the 1940s under the name of the so-called "golden age antibiotics", many countries around the world of progress. Intensive program to increase the number of antibiotics described or to find someone new (Abussaud et al., 2013). Overtime, the number of multi drug-resistant pathogenic microbes has increased, and there are only a limited number of treatments available to combat these pathogens. Therefore, in order for treatment to be effective under antibiotics, continuous discovery of new, new antibiotics is required (Lehan et al., 2014). Considering the recent emergence of new antibiotics to combat multidrag resistant pathogens, new approaches to antibiotic discovery are needed. One of the richest sources of new antibiotics may be uncultivated soil microorganisms (Gillespie et al., 2002). The isolation and purification methods of antibiotics largely depend on the properties of the antibiotic, its chemical nature, and the environment (El Nagar, 2001). Antibiotics have been described as microbial products that inhibit the growth of other microorganisms (Pivitra et al., 2015). 5,000 antibiotics have been identified from cultures of hot positive and gram-negative organisms, but it contains only 100 antibiotics commercially used to treat human, animal and plant diseases (Basavaraj et al., 2010). About 70 to $80 \%$ of all antibiotics found during this time are derived from actinomycetes, and from various species of Streptomyces (Norden fuji, 2014). As the most important bacteria in the soil due to the preparation of important antibiotics (Kaur et al., 2014). The amount of antibiotics produced by Bucillia was approaching 167. More than 66 and about 23 B-brevis (Jamil et al., 2007) were born from B. sybilis. Preparations of large-spectrum bacilli and antibacterial antibiotics that are effective against Gram-negative bacteria are relatively rare (Yilmaz et al., 2006). Actinomycetes contain a broad and diverse group of Gram-positive, aerobic, mycelial bacteria that play an important ecological role in soil cycles. Many people are known for their economic importance in the preparation of biologically active substances such as antibiotics, vitamins, and enzymes (Basillo et al., 2003). The genus Streptomyces is responsible for the formation of more than 60 of the unknown antibiotics (Surwani et al., 2012). In their natural habitat, bacteria use the antibiotics they produce as a protective substance by attacking other bacterial species. Protection is not just about antibiotics. Therefore, antibiotics also act as signaling molecules that are used by bacteria as a means of communication between cells (Lehan et al., 2014). Clearly, antibiotics also contain a chemically heterogeneous group of microorganisms of microbial origin that, at low concentrations, are detrimental to the growth or metabolic activity of other microorganisms (Thomsho et al., 2005). In a sensitive bacterial population, there may be a small number of drug-resistant bacteria that suddenly become resistant to mutations.

\section{MATERIALS AND METHODS}

\subsection{Collection and Preparation of Soil Sample:}

Soil samples were collected from different parts of Khyber Pakhtunkhwa, Pakistan. All these samples were collected from the upper layer using some clean dry sterile polythene bags.

\subsection{Isolation of Bacteria:}

The media used in this study was the nutrition of Agar Medium. 


\subsection{Sample Inoculation:}

Different soil suspensions are inoculated on the growthnourishing agar and then heated to $37{ }^{0} \mathrm{C}$ for $24 \mathrm{~h}$. After which the colonies were observed.

\subsection{Sub Culturing:}

We pick a colony from the master plate and streak it to another plate that contains nutrient media. After this place in the incubator for 24 hours at $37^{\circ} \mathrm{C}$ then we do gram staining and various biochemical tests.

\subsection{Gram's Staining:}

In the colonies that grow on nutrients where the gram is in accordance with the standard method of staining.

\subsection{Biochemical Tests:}

\subsubsection{Indole test:}

Bacteria, which express the enzyme tryptophanase, can hydrolyze the amino acid tryptophan into indole, pyruvic acid and ammonia.

\subsubsection{Citrate use test:}

This was done by inoculating the test organism in a test tube containing Simon Citrate Medium dark blue after incubation indicates a positive result to be used to determine if an organism can use citrate as its sole carbon source.

\subsubsection{Triple Sugar Iron Agar Test (TSI):}

The medium contains three sugars namely: glucose, lactose and sucrose, $\mathrm{pH}$ indicator is phenol red and detection system for hydrogen sulphide $(\mathrm{H} 2 \mathrm{~S})$.

\subsubsection{Catalase Test:}

This was carried out by putting a drop of hydrogen peroxide on a clean slide. Presence of bubbles indicates positive reaction while absence of bubble indicates negative reaction.

\subsubsection{Oxidase Test:}

In the oxidase test, artificial electron donors and acceptors are provided. When the electron donor is oxidized by cytochrome oxidase it turns a dark purple. This is considered a positive result.

\subsubsection{Coagulase Test:}

Coagulase is a virulence factor of $S$. aureus. The formation of clot around an infection caused by these bacteria likely protects it from phagocytosis. This test differentiates Staphylococcus aureus from other coagulase negative Staphylococcus species.

\subsubsection{Urease Test}

This test is used to identify bacteria capable of hydrolyzingurea through enzyme ureases.

\subsubsection{Test Bacteria:}

The test bacteria used in this study was obtained from the Microbiology laboratory of Abasyn University including, Salmonella typi, S. paratypi, Citrobacter, orgenella morgani, Proteus, P. areuginosa and E.coli.

\subsubsection{Pustule Method:}

In this method we make a pathogenic lawn than we take pustulefrom the old culture of soil isolates and place in a circle on the surface of that pathogenic lawn and then incubate for $24 \mathrm{hr}$ at $37^{\circ} \mathrm{C}$. After clear zone are observed which indicate antibiotic producing bacteria.

\subsection{Confirmation of Antibacterial Activity}

Bacterial isolates have the potential of producing antibioticwere tested against the test organisms to confirm the antibacterial activity. 


\section{RESULTS AND DISCUSSIONS}

I collected 150 soil samples from different KhyberPakhtunkhwa (Pakistan) locations. Which shows positiveresults against 12 to 20 different pathogenic species listed in Table 1. I first apply the gram stain, and then the results of the various biochemical tests mentioned in Table 1. After that we confirm the anti-microbial activity through the Streak method and the Pustule method. Soil bacteria show some activity against gram-positive bacteria separately, while others show activity against gram-negative bacteria as shown in Table 2 along with zones of inhibition. In current study, we have seen a zone of up to $40 \mathrm{~mm}$ against proteus, which is the largest zone in all research studies. In my study, the smallest zone against Proteus is $12 \mathrm{~mm}$, which was the largest zone in this study (Abdulkadir and Waliyu, 2012). They also observed that E. coli shows resistance to soil isolation while we observed a clear zone up to $15 \mathrm{~mm}$ against the $E$. coli of our soil isolation and the smallest zone observed. He was 10 millimeters while showing resistance to some antibiotics. Other studies show that the highest zone of isolated areas of the soil against $E$. coli is $22 \mathrm{~mm}$. In the study conducted by Mashoria et al., 2014 and Kalyani et al., 2012). a zone of up to $12.5 \mathrm{~mm}$ was observed against E. coli. Clear zone against P.aerogenos was observed in our study which was similar to the study of (Sandhya et al., 2014). According to (Mashoria1 et al., 2014), P. aergenosa has been observed to have a maximum area of $30 \mathrm{~mm}$. (Nike et al., 2013) The largest area and the smallest area of $10 \mathrm{~mm}$. When studied in the soil, it also shows resistance in some different places. In the case of of S.typi, $21 \mathrm{~mm}$. Due to review study similar results, which is also found in the study (Mashoria1 et al.,2013) The highest zone against S.typi in their study was $28 \mathrm{~mm}$ while in our study was $21 \mathrm{~mm}$. S.typi also show resistant toward certain soil isolates which also similar to the previous Citrobacter study. The clear zone against P.pyogen in our study ranges from $5 \mathrm{~mm}$ to $18 \mathrm{~mm}$ which is a slight difference in our study and the study conducted by(Kizito and Nwankwo, 2013). The highest zone in their study was $20 \mathrm{~mm}$ which is almost similar to our study that is $18 \mathrm{~mm}$. S.pyogen show resistant to certain soil isolates also similar to the previous study. No study were found about S.paratypi it show complete resistant to all soil isolates in our study as it is the most pathogenic spp. We also used and Morgenella morganii such pathogenic strain was not used by other researcher as no results were found about it in their study. The highest zone against Citrobacter in our study are $22 \mathrm{~mm}$. while other zones of $5 \mathrm{~mm}, 10 \mathrm{~mm}, 12 \mathrm{~mm}$ and $15 \mathrm{~mm}$ are also observed. Also show resistant to certain soil isolates. In case of Morgenella morganii highest zone are $15 \mathrm{~mm}$ and other zones of $5 \mathrm{~mm}, 10 \mathrm{~mm}$ and $12 \mathrm{~mm}$ are present. Show resistant to certain soil isolates as mentioned in the above table no 2. In the last we used different antibiotics along with our soil isolates against different pathogenic species. Clear and largest zones was producing by our soil isolates while antibiotic show weak activity against different pathogenic strain. We had done further characterization based on which we identify our soilisolates. Rhizobacteria are present in the soil in an average of about 108 cells per gram (Stein, 2005). B. subtilis is also a Rhizobacterium and an endospore forming bacteria (Sonenshein et al., 2001). The present study was carried out to evaluate the production of antibiotic from newly isolated Bacillus specie from soil-by-soil sprinkling method, which was identified as $B$. subtilis by performing various. By using soil sprinkle method five various size colonies having zones of inhibition were picked and streaked on nutrient agar plates to get pure cultures. Out of all strains the one showing maximum inhibition zone was selected for optimization (Awais et al., 2010). Antibiotics used in my study are Azithromycin, Amikacin, Nalidixic Acid, Doxycycline and Pipracilline. All the results are present in the above table no 3. According to these B11 and B12 show the highest zone which are $40 \mathrm{~mm}$ and $32 \mathrm{~mm}$ and other are $21 \mathrm{~mm}$ and $15 \mathrm{~mm}$ are produced against E. coli, P.aerogenosa, Proteus and Citrobacter. 


\section{Current Trends in Natural Sciences}

Vol. 10, Issue 19, pp. 407-415, 2021

https://doi.org/10.47068/ctns.2021.v10i19.054

Current Trends in Natural Sciences (on-line)

ISSN: 2284-953X

Current Trends in Natural Sciences (CD-Rom)

ISSN: 2284-9521

ISSN-L: 2284-9521

ISSN-L: 2284-9521

While in case of B12 $30 \mathrm{~mm}$ is the highest zone and $22 \mathrm{~mm}, 12 \mathrm{~mm}$ and $5 \mathrm{~mm}$ of zones are also observed against all the other pathogenic spp. In case of antibiotics Azitheromcin show the highest activity against Proteus and $20 \mathrm{~mm}$ of zone was observed another $10 \mathrm{~mm}$ of zone are also measure produced by Azitheromcin against S.aergenosa. Amikacin produced two zones of $5 \mathrm{~mm}$ while no other clear zone are observed by Amikacin against S.aergenosa and Citrobacter. Doxicycline produced $30 \mathrm{~mm}$ of zone against $E$. coli and $12 \mathrm{~mm}$ of zones against Proteus while show resistant toward Citrobacter and P.aergenosa. Nalidixic Acid show resistant to E. coli except one clear zone of $15 \mathrm{~mm}$ was observed against Proteus. Pipracilline produced $21 \mathrm{~mm}, 12 \mathrm{~mm}$ and $5 \mathrm{~mm}$ of zone against S.aergenosa, Citrobacter and Proteus. In the end we concluded that highest zones were produced by our soil isolates and antibiotic disc against $E$. coli

and Proteus as compare to other pathogenic spp.

In Table- 1 and Table-2 Show the antimicrobial Activity of Antibiotics producing bacteria isolated from soil with different pathogenic microorganisms. While in Table-3 the antimicrobial activity of soil isolates e.g B11and B12 were compared with different antibiotics like Amikacin, Azitheromycin, Doxicyclin, NaliDixic Acid.

Table 1. Morphology and biochemical characterization of bacterial isolation

\begin{tabular}{|c|c|c|c|c|c|c|c|c|c|c|c|}
\hline BI & \multicolumn{2}{|c|}{$\mathbf{C M}$} & \multirow{3}{*}{ Oxidase } & \multicolumn{8}{|c|}{ Biochemical Test } \\
\hline & \multirow[t]{2}{*}{ Shape } & \multirow[t]{2}{*}{$\begin{array}{c}\text { Gram } \\
\text { Reaction }\end{array}$} & & \multirow[t]{2}{*}{ Catalase } & \multirow[t]{2}{*}{ Coagulase } & \multirow[t]{2}{*}{ Citrate } & \multirow[t]{2}{*}{ Indol } & \multirow[t]{2}{*}{ Ureases } & \multicolumn{3}{|c|}{$\begin{array}{c}\text { Sugar Fermentation/Triple } \\
\text { sugar iron test }\end{array}$} \\
\hline & & & & & & & & & Glucose & Sucrose & Lactose \\
\hline B1 & Rod & + & - & + & + & - & - & - & - & - & - \\
\hline B2 & Cocci & + & - & + & + & - & - & - & _ & - & - \\
\hline B3 & Rods & - & - & - & - & + & + & - & $\mathrm{AG}$ & $\mathrm{AG}$ & $\mathrm{AG}$ \\
\hline B4 & Cocci & - & - & - & - & + & + & - & A & $\mathrm{A}$ & A \\
\hline B5 & Cocci & + & - & + & - & - & - & - & - & - & - \\
\hline B6 & Cocci & + & . & + & + & - & - & - & - & - & - \\
\hline B7 & Rods & - & - & - & - & + & - & + & A & $\mathrm{A}$ & $\mathrm{A}$ \\
\hline B8 & Rods & - & - & - & - & + & + & + & $\mathrm{A} \mathrm{G}+\mathrm{H} 2 \mathrm{~S}$ & $\begin{array}{c}\mathrm{A} \\
\mathrm{G}+\mathrm{H} 2 \mathrm{~S}\end{array}$ & $\begin{array}{l}\text { A G+ } \\
\mathrm{H} 2 \mathrm{~S}\end{array}$ \\
\hline B9 & Rod & - & - & - & - & + & - & + & - & - & - \\
\hline B10 & $\begin{array}{l}\text { Cocci in } \\
\text { chain }\end{array}$ & - & - & - & - & - & - & + & $\mathrm{A} \mathrm{G}+\mathrm{H} 2 \mathrm{~S}$ & $\begin{array}{c}\mathrm{A} \\
\mathrm{G}+\mathrm{H} 2 \mathrm{~S}\end{array}$ & $\begin{array}{l}\text { A G+ } \\
\mathrm{H} 2 \mathrm{~S}\end{array}$ \\
\hline B11 & Rods & + & - & + & + & - & - & - & - & - & - \\
\hline B12 & Rods & + & - & - & + & - & & - & - & - & - \\
\hline
\end{tabular}

$A=$ Acid Production, $A G=$ Acid and gas production $B I=$ bacterial isolates, $C M=$ colonial morphology 


\section{Current Trends in Natural Sciences}

Vol. 10, Issue 19, pp. 407-415, 2021

https://doi.org/10.47068/ctns.2021.v10i19.054

Current Trends in Natural Sciences (on-line)

Table 2. Antimicrobial activity of bacterial isolated from soil

\begin{tabular}{|l|l|l|l|l|l|l|l|l|}
\hline $\begin{array}{l}\text { Screen } \\
\text { isolates }\end{array}$ & \multicolumn{9}{l}{$\begin{array}{l}\text { Sampled to be inhibited } \\
\text { Organisms }\end{array}$} \\
\hline & E. coli & $\begin{array}{l}\text { Salmonella } \\
\text { typi }\end{array}$ & $\begin{array}{l}\text { Salmonella } \\
\text { paratypi }\end{array}$ & Proteus & P. aerogenosa & S. pyogen & Citrobacter & $\begin{array}{l}\text { Morgenella } \\
\text { morganii }\end{array}$ \\
\hline B1 & $12 \mathrm{~mm}$ & Nil & Nil & $12 \mathrm{~mm}$ & Nil & Nil & $12 \mathrm{~mm}$ & $10 \mathrm{~mm}$ \\
\hline B2 & $15 \mathrm{~mm}$ & $5 \mathrm{~mm}$ & Nil & $21 \mathrm{~mm}$ & $12 \mathrm{~mm}$ & $9 \mathrm{~mm}$ & $18 \mathrm{~mm}$ & Nil \\
\hline B3 & $5 \mathrm{~mm}$ & $10 \mathrm{~mm}$ & Nil & $30 \mathrm{~mm}$ & Nil & Nil & $22 \mathrm{~mm}$ & Nil \\
\hline B4 & Nil & $12 \mathrm{~mm}$ & Nil & $40 \mathrm{~mm}$ & Nil & Nil & $12 \mathrm{~mm}$ & Nil \\
\hline B5 & Nil & Nil & Nil & $45 \mathrm{~mm}$ & Nil & Nil & Nil & $12 \mathrm{~mm}$ \\
\hline B6 & Nil & Nil & Nil & $25 \mathrm{~mm}$ & Nil & Nil & Nil & $5 \mathrm{~mm}$ \\
\hline B7 & $15 \mathrm{~mm}$ & Nil & Nil & $15 \mathrm{~mm}$ & Nil & Nil & Nil & $5 \mathrm{~mm}$ \\
\hline B8 & Nil & Nil & Nil & $16 \mathrm{~mm}$ & $15 \mathrm{~mm}$ & $15 \mathrm{~mm}$ & $15 \mathrm{~mm}$ & $10 \mathrm{~mm}$ \\
\hline B9 & Nil & $21 \mathrm{~mm}$ & Nil & $35 \mathrm{~mm}$ & Nil & $21 \mathrm{~mm}$ & $5 \mathrm{~mm}$ & $15 \mathrm{~mm}$ \\
\hline B10 & Nil & Nil & Nil & $12 \mathrm{~mm}$ & $12 \mathrm{~mm}$ & Nil & $10 \mathrm{~mm}$ & $12 \mathrm{~mm}$ \\
\hline B11 & $10 \mathrm{~mm}$ & $15 \mathrm{~mm}$ & Nil & $40 \mathrm{~mm}$ & $21 \mathrm{~mm}$ & $18 \mathrm{~mm}$ & $15 \mathrm{~mm}$ & $15 \mathrm{~mm}$ \\
\hline B12 & $12 \mathrm{~mm}$ & $10 \mathrm{~mm}$ & Nil & $30 \mathrm{~mm}$ & $12 \mathrm{~mm}$ & $5 \mathrm{~mm}$ & $5 \mathrm{~mm}$ & Nil \\
\hline B13 & $15 \mathrm{~mm}$ & Nil & Nil & $21 \mathrm{~mm}$ & $14 \mathrm{~mm}$ & $12 \mathrm{~mm}$ & $15 \mathrm{~mm}$ & $12 \mathrm{~mm}$ \\
\hline
\end{tabular}

Table 3. Comparison of antimicrobial activity of soil isolate with antibiotic discs

\begin{tabular}{|l|l|l|l|l|l|l|l|}
\hline PS & B11 & B12 & Azithromycin & Amikacin & Doxicycline & NalidixicAcid & Pipracilline \\
\hline E. coli & $32 \mathrm{~mm}$ & $22 \mathrm{~mm}$ & $\mathrm{R}$ & $5 \mathrm{~mm}$ & $30 \mathrm{~mm}$ & $\mathrm{R}$ & $\mathrm{R}$ \\
\hline P. aergenosa & $21 \mathrm{~mm}$ & $12 \mathrm{~mm}$ & $10 \mathrm{~mm}$ & $\mathrm{R}$ & $\mathrm{R}$ & $\mathrm{R}$ & $5 \mathrm{~mm}$ \\
\hline Citrobacter & $15 \mathrm{~mm}$ & $5 \mathrm{~mm}$ & $\mathrm{R}$ & $\mathrm{R}$ & $\mathrm{R}$ & $\mathrm{R}$ & $12 \mathrm{~mm}$ \\
\hline Proteus & $40 \mathrm{~mm}$ & $30 \mathrm{~mm}$ & $20 \mathrm{~mm}$ & $5 \mathrm{~mm}$ & $12 \mathrm{~mm}$ & $15 \mathrm{~mm}$ & $21 \mathrm{~mm}$ \\
\hline
\end{tabular}

$\mathrm{BI}=$ Bacterial Isolates, $\mathrm{PS}=$ Pathogenic strains, $\mathrm{R}=$ Resistant
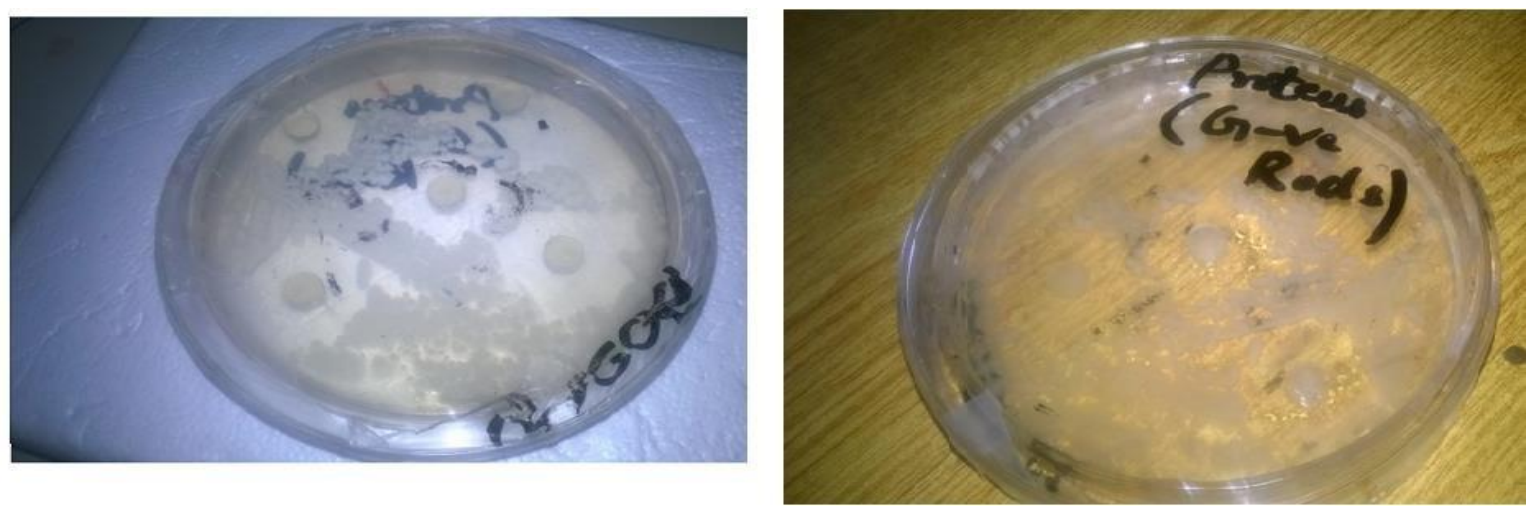

Figure 1. Activities of soil isolates against various pathogenic Bacteria 


\begin{tabular}{|c|c|}
\hline & \\
\hline $\begin{array}{l}\text { Current Trends in Natural Sciences (on-line) } \\
\text { ISSN: 2284-953X } \\
\text { ISSN-L: 2284-9521 }\end{array}$ & $\begin{array}{r}\text { Current Trends in Natural Sciences (CD-Rom) } \\
\text { ISSN: 2284-9521 } \\
\text { ISSN-L: 2284-9521 }\end{array}$ \\
\hline
\end{tabular}
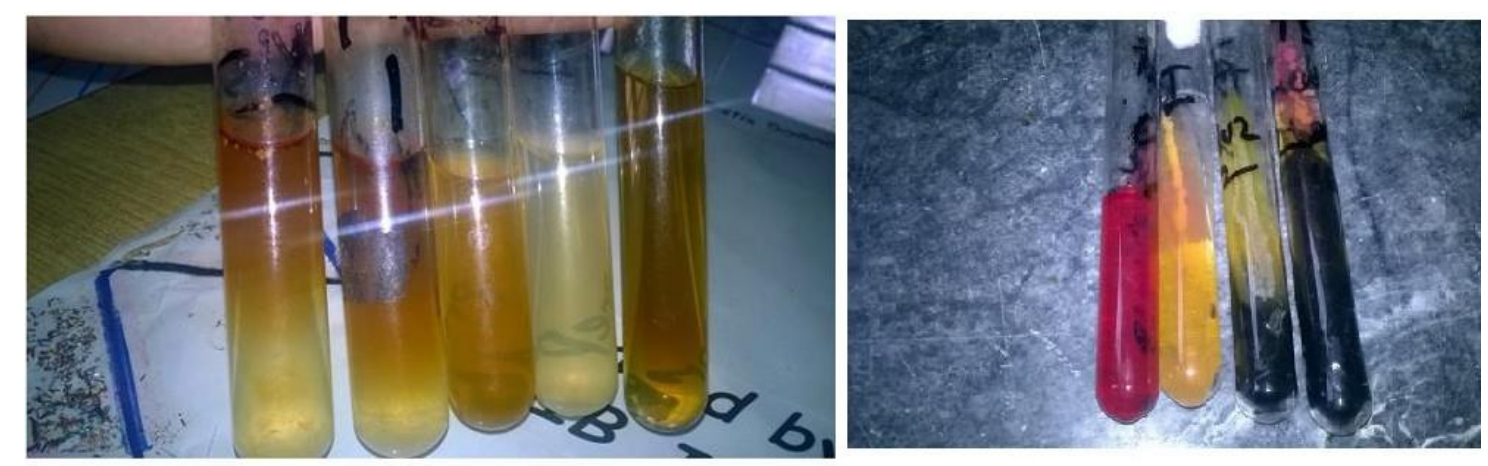

Figure 2. Results of Biochemical tests for soil isolates identifications

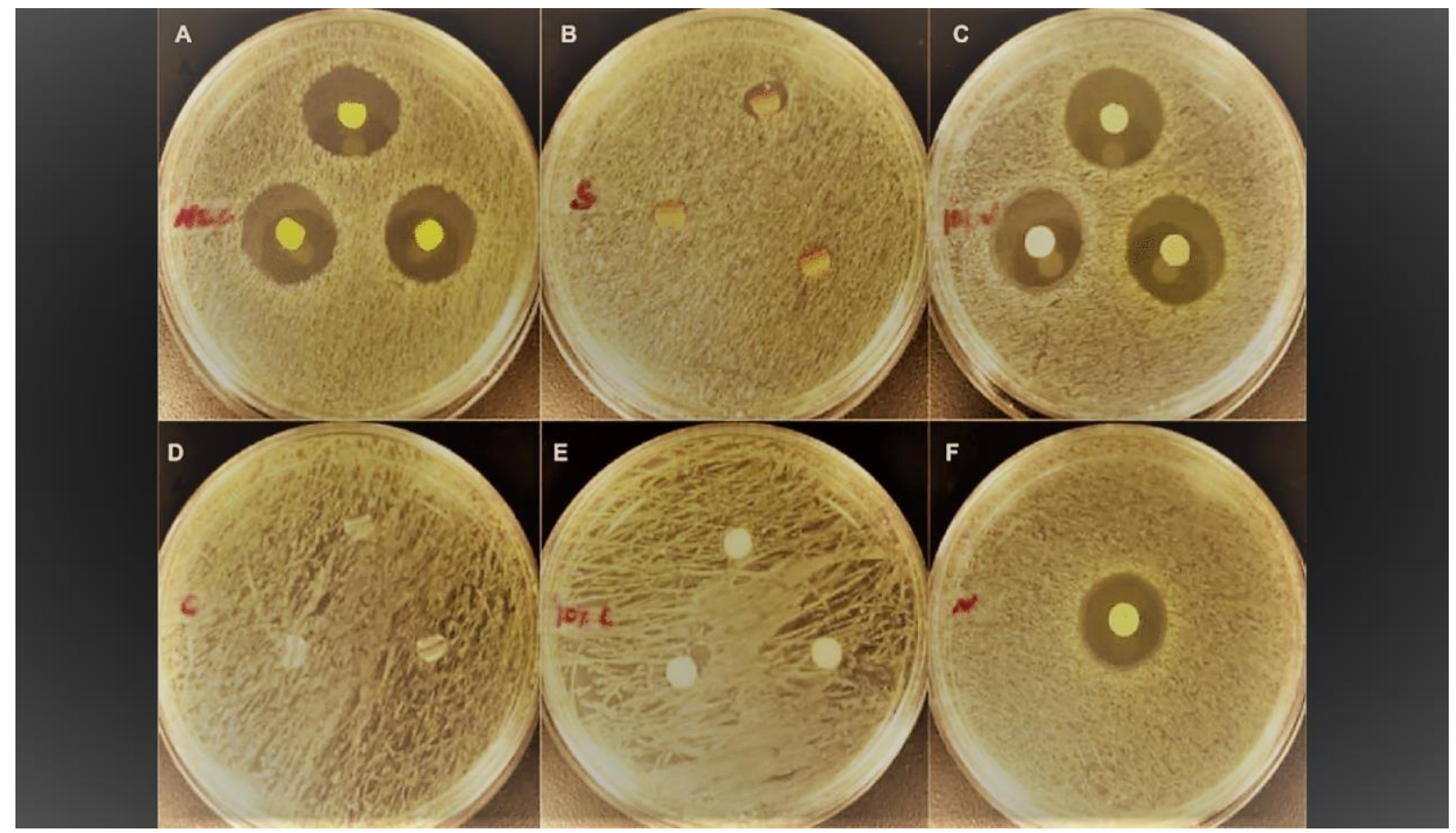

Figure 3. Activities of soil isolates against various antibiotics disc

\section{CONCLUSIONS}

- It has been concluded that soil is a natural source of many types of microbial populationsand plays an important role in production novel antibiotics against various infectious diseases.

- In the present study, we isolate bacterial strains that exhibit more resistant ward pathogenic bacteria than antibiotic discs, as described in Table 3.

\section{ACKNOWLEDGEMENT}

I am thankful to my teachers the faculty member of Abasyn University Peshawar, Pakistan the Technical staff of Microbiology Laboratories and the research support of our Head of the Department Dr Shabir Ahmad. In the last but not the least the unconditional support of my family 
specifically my parents Mr. and Mrs. Khan Bahadar and last but not the least my brother Engr. Izaz Ali.

\section{REFERENCES}

Abdulkadir, M., Waliyu, S. (2012). Screening and Isolation of the Soil Bacteria for Ability to Produce Antibiotics. European Journal of Applied Sciences. 4 (5), 211-215.

Abussaud., M.J., Alanagreh, L., Abu-Elteen, K. (2013). Isolation, Characterization and Antimicrobial Activity of Streptomyces Strains from Hot Spring Areas in The Northern Part of Jordan. African Journal of Biotechnology. 12(51), 7124-7132.

Al Wahed Mahdi, S.A. (2015). Effect of Different Factors on Production of Bacterial Antibiotics. European Academic Research. 2(11), 1-4.

Awais., M, A. Pervez, Asim Yaqub, Shah, M.M. (2010). Production of Antimicrobial Metabolites by Bacillus subtilis Immobilized in Polyacrylamide Gel. Pakistan J. Zool.42(3), 267-275.

Basavaraj, N.K, Chandrashekhara, S., Shamarez, A.M., Goudanavar, P.S., Manvi, F.V. (2010). Isolation And Morphological Characterization of Antibiotic Producing Actinomycetes. Tropical Journal of Pharmaceutical Research. 9 (3), 231-236.

Basilio.,A, I. Gonza' lez, M.F. Vicente, J. Gorrochategui, A. Cabello, A. Gonza'lez and O.

Ceylan., O, Okmen, G., Ugur, A. (2008). Isolation of soil Streptomyces as source antibiotics active against antibioticresistant bacteria. EurAsian Journal of BioSciences.4(8), 73-82.

Chandan., P, Mishra, R.P., Asif, A., Gangwar, V.S., Shweta, C. (2013). Isolation and Characterization of Multi drug Resistant Super Pathogens from soil Samples Collected from Hospitals. Research Journal of Recent Sciences.2(2), 124- 129.

Chang Wu.,X, X.Bo Shen, R. Ding, C.D.Qian, H.Huan Fang \& O.Li.2010.solationand partial characterization of antibiotics produced by Paenibacillus elgii B69.Institute of Microbiology, College of Life Sciences, Zhejiang University, Hangzhou. 10(11), 1574-6968.

Dancer, S.J. (2004). How antibiotics can make us sick: the less obvious adverse effects of antimicrobial chemotherapy. The Lancet Infectious Diseases, 4, 611-619.

Dantas., G, M.O.A.Sommer,R.D.Olusungan, Church, G.M. (2008). Bacteria subsisting on antibiotic. The worldleading journal of original science. 320 (5872): 100-103.

El-Naggar.,M.Y, Hassan, M.A., Wafa Y. (2001). Isolation And Characterisation Of An Antimicrobial Substance Produced By Streptomyces Violates. Botany \& Microbiology Department, Faculty of Science Alexandria University.2(1), 11-21.

Euanorasetr, J, A. Nilvongse, S. Tantimavanich, T. Nihira, Y. Igarashi and Watanalai. Panbangred. (2010). Identification and Characterization of Soil-Isolated Streptomyces $\quad$ Sje177 Producing Actinomycin. Southeast Asian JTrop Med Public From genes to cells. American Society for Microbiology,Washington. 25, 81-84.

Genilloud. (2003). Patterns of antimicrobial activities from soil actinomycetes isolated under different conditions of $\mathrm{pH}$ and salinity.Journal of Applied Microbiology. 95(2), 814-823.

Gillespie.,D.E, S. F. Brady, A. D. Bettermann1 ,N. P. Cianciotto, M. R. Liles, M. R. Rondon, J. Clardy, R. M. Goodman, And J. Handelsman. (2002). Isolation Of Antibiotics.Health.41(5), 1177-1190.

Jamil.,B, F. Hasan, A. Hameed And Safia Ahmed (2007). Isolation Of Bacillus Subtilis Mh-4 From Soil and Its Potential of Polypeptidic Antibiotic Department of Microbiology, Faculty of Biological Sciences.20(1), $26-31$.

Kalyal., A.L. T, R.Sravani, Ann J.Apurna. (2012). Isolation And Characterization Of Antibiotic Producing Actinomycetes From Marine Soil Samples. International Journal of Current Pharmaceutical Research.4(2), 109112.

Kalyani.,A.L.T, R. Sravani K And M .Annapurna (2012). Isolation And Characterization of Antibiotic Producing Actinomycetes from Marine Soil Samples. International Journal of Current Pharmaceutical Research.4(2), 109112.

Kaur.,S, J. Kaur, and P. P Pankaj (2014). Isolation And Characterization of Antibiotic Producing Microorganisms from Soil Samples of Certain Area of Punjab Region of India. International Journal of Pharmaceutical and Clinical Research.6(4), 312-315.

Kizito.,B.E and E.O. Nwankwo (2013). Antibiotic Activity of Streptomyces Isolates Collected from Soil of Kogi Central, NigeriaJournal of Pharmacy and Biological Sciences, 5(6), 2278-3008. 


\section{Current Trends in Natural Sciences}

Vol. 10, Issue 19, pp. 407-415, 2021

https://doi.org/10.47068/ctns.2021.v10i19.054

Lihan., S, S.C.Lin, I.Ahmad, F .M.Sinang, N.K.Hua And A.A.Sallehin (2014). Antimicrobial Producing Microbes Isolated from Soil Samples Collected Fromnanga Merit Forest in Sarawak, Malaysian Borneo. European Journal of Experimental Biology, 4(1), 494-501.

Mashoria1., A, H.S. Lovewanshi and B.S. Rajawat (2014). Isolation Of Antimicrobial Producing Bacteria from Soil Samples Collected from Bhopal Region of Madhya Pradesh, India.International Journal of Applied Sciences. 3(12), 563-569.

Mathura.,N, A.Paliwala, P.Sharmaa, M.Kumara and P.Bhatnagar (2012). Antimicrobial Compound from Streptomyces Isolate Characterized Using HPL Journal of Environmental Research and Technology.2(4), 242-246.

Nike.,R, Ahmed, Sani, A. Hassan, Ajijolakewu, Alamu, F. Bosede (2013). Soil Screening for Antibiotic Producing Microrgansms. Advances in Environmental Biology. 7(1), 7-11.

Nordenfjäl., E. (2014). Isolation Of Antibiotic Producing Microorganisms by Screening for Antibiotic Resistance. Faculty Of Natural Resources and Agricultural Sciences.2(1), 40-42.

Pavithra1., S, R.Amsaveni, M.Sureshkumar And G. Vivekanandhan (2010). Isolation And Characterization of Antibacterial Compound from Bacteria Isolated from Vegetable Waste Dumped Soiles.World Journal of Pharmacy and Pharmaceutical Scienc.4(2), 2278-4357.

Sandhya.,M.S, E.Ramyakrishna., P.Divya., A.P. Kumar, K. Rajkumar, E. Yazein, And S. Burgula (2015). Isolation Of Antibiotic Producing Bacteria from Soil.International Journal of Applied Sciences and Pharmaceutical Technology.6(1), 46-51.

Sarkar.,P, S. Bhagavatula and V. Suneetha (2014). A brief research study on novel antibiotic producing isolate from VIT Lake, Vellore, Tamil Nadu. Journal of Applied Pharmaceutical Science. 4 (01), 061-065.

Sarker., D, N.Roy and Yeasmin (2010). Isolation and antibiotic sensitivity of Bacillus thuringinesis strain from dump soil. Malaysian Journal of Microbiology. 6(2), 127-132.

Singh.,A.P and S.Mishra (2013). solation and Biochemical Characterization of Antibiotic Producing Microorganism from Waste Soil Samples of Certain Industrial areas of Indi. School of Biotechnology, IFTM University, Lodhipur Rajput.5(6), 80-89.

Soenshein., A.L, Hoch, J.A. And Losick, R. (2001). Bacillus subtilis and its closest relatives.From genes to cells.American Society for Microbiology, Washington.25, 81-84.

Stein., T. (2005). Bacillus subtilis antibiotics: structures, syntheses, and specific functions. Mol. Microbiol.56, 845-851. Turbomycin A and B from A Metagenomic Library of Soil Microbial Dna. Applied And Environmental Microbiology.86(9), 4301-4306.

Wilson., M. (2013). Isolation and Identification of Antimicrobial-Producing Microbes from Soil Associated with an Eastern Hemlock in the Great Smoky Mountains National Park Journal of Undergraduate Research Asheville, North Carolina.1(1), 1-8.

Yilmaz.,M, H. Soran, and Y. Beyatli, Y. (2006). Antimicrobial activities of some Bacillus spp strains isolated from the soil. Microbiological Research. 161(1), 127-131. 